\title{
Biochemical and Genetic Characterization of nirB Mutants of Escherichia coli K12 Pleiotropically Defective in Nitrite and Sulphite Reduction
}

\author{
By J. A. COLE,* B. MARY NEWMAN† AND PAMELA WHITE \\ Department of Biochemistry, University of Birmingham, P.O. Box 363, Birmingham B15 $2 T T$
}

(Received 15 April 1980)

Mutants of Escherichia coli $\mathrm{K} 12$ defective in the nirB gene lack NADH-dependent nitrite reductase activity and reduce nitrite slowly during anaerobic growth. With one exception, these mutants require cysteine for growth. Cytochrome $c_{552}$ synthesis and the assimilation of ammonia are unaffected by the nir $B$ mutation. The defective gene is located between the $\operatorname{crp}$ and $\operatorname{aroB}$ genes at minute 73 on the $E$. coli chromosome. Mapping and reversion studies indicate that $\operatorname{nir} B$ is identical to the previously described $c y s G$ gene. It is suggested that the product of the cys $G^{+}\left(\right.$nir $\left.B^{+}\right)$gene is an enzyme required for the synthesis of sirohaem, a prosthetic group of enzymes which catalyse the six-electron reduction of nitrite to ammonia and sulphite to sulphide.

\section{INTRODUCTION}

We recently reported the isolation of mutants of Escherichia coli $\mathrm{K} 12$ which are unable to reduce nitrite to $\mathrm{NH}_{4}{ }^{+}$during anaerobic growth (Newman \& Cole, 1978). Some of these mutants were defective in the nir $A$ gene located at minute 29 on the recalibrated linkage map of Bachmann et al. (1976) and were therefore similar to the mutants described by Cole $\&$ Ward (1973). The product of the nir $A^{+}$gene is essential for nitrite reduction and for the synthesis or assembly of a variety of anaerobic redox enzymes which include cytochrome $c_{552}$, nitrate reductase, fumarate reductase and formate hydrogenlyase. The nir $A$ gene is identical to the $f n r$ gene described by Lambden \& Guest (1976) and the pleiotropic NirRphenotype described by Chippaux et al. (1978) is probably also due to a defective nir $A$ gene.

A second group of mutants appeared to lack only the NADH-dependent nitrite reductase activity (EC 1.6.6.4; Coleman et al., 1978). It was possible, therefore, that these NirBmutants were defective in a second gene, $\operatorname{nir} B$, which is essential for nitrite reduction and that $\operatorname{nir} B$ is the structural gene for NADH-nitrite oxidoreductase. We now report the biochemical properties of isogenic nirB and nir $B^{+}$strains and chromosomal location of the nir $B$ gene with reference to the $r p s L, c r p, c y s G, a r o B$ and mal genes (Bachmann et al., 1976). We also suggest a possible function for the nir $B^{+}$gene product.

\section{METHODS}

Organisms. The origins of the various strains of Escherichia coli $\mathrm{K} 12$ are listed in Table 1. Bacteria were stored at $4^{\circ} \mathrm{C}$ as stab cultures in nutrient agar deeps (Oxoid CM1).

Media and growth conditions. Minimal agar for selective media contained (per litre distilled water): $10.5 \mathrm{~g} \mathrm{~K}_{2} \mathrm{HPO}_{4} ; 4.5 \mathrm{~g} \mathrm{NaH}_{2} \mathrm{PO}_{4} ; 1 \mathrm{~g}$ trisodium citrate. $2 \mathrm{H}_{2} \mathrm{O} ; 125 \mathrm{mg} \mathrm{Na} \mathrm{SO}_{4} ; 4 \mathrm{~g}$ glucose or other carbon

\footnotetext{
$\dagger$ Present address: Faculty of Health Sciences, University of Ilorin, P.M.B. 1515, Ilorin, Nigeria.
} 


\section{Table 1. Escherichia coli strains and their origins}

Strain Relevant phenotype or genotype*

AB312

AB2847

CB63

CB68

CB69

CB88

CB89

CB98

CB201

CB203

CB211

CB213

CB217

JM72

KL209

$\mathrm{KLF} 33 / \mathrm{JC1} 1553$

KLF41/JC1553

Lin13

$\operatorname{Lin} 72$

OR56

OR75

W1485E

22A43 leu rpsL $\mathrm{Hfr}$

aroB351 mal-354

nirB201 pro thr metB rpsL

nirB201 $\mathrm{mal} \mathrm{leu}^{+}$

nirB201 ilv argA rpsL

nirB203

nirB202 Cys $^{-} \mathrm{Mal}^{-}$

nirAl trp his rpsL

nirB20I chl $\mathrm{Cym}^{-} \mathrm{Hfr}$

nirB203

nir $A 3$ unknown growth requirement

nirB213 $\mathrm{Cym}^{-}$

nirB217 $\mathrm{Cym}^{-}$

cysG rpsL $\mathrm{Mal}^{-}$

Hfr with $\mathrm{F}$ integrated into $\mathrm{malB}$

$\mathrm{F}^{\prime}$ ilv $^{+} \arg \mathrm{H}^{+}$

$\mathrm{F}^{\prime} \mathrm{cys}_{\mathrm{s}} \mathrm{G}^{+}$aroB $^{+} \mathrm{mal}^{+}$

DE44 (bioH to glpD) $\Delta$

DE14 (glpR5 to malA34) $\Delta$

Prototrophic Hfr

Prototrophic Hfr

Prototroph, lysogenic for P1 kc

his pro ilv metB argA mal rpsL
Source or method of isolation $\dagger$

B. Bachmann; E. coli Genetic Stock Center

B. Bachmann

Conjugate strain 22A43 with CB201 for $3 \mathrm{~h}$; select streptomycin-resistant $\mathrm{Leu}^{+}$recombinants and screen for $\mathrm{Nir}^{-}$

As for CB63

Conjugate strain $22 \mathrm{~A} 43$ with $\mathrm{CB} 201$ for $3 \mathrm{~h}$; select streptomycin-resistant $\mathrm{Mal}^{+}$recombinants and screen for $\mathrm{Nir}^{-}$

Transduce AB2847 to $\mathrm{Aro}^{+}$with $\mathrm{P} 1$ propagated on CB203

Transduce AB2847 to $\mathrm{Aro}^{+}$with $\mathrm{P} 1$ propagated on JM72

See Newman \& Cole (1977)

NG mutagenesis of OR56

NG mutagenesis of OR56

NG mutagenesis of OR75

EMS mutagenesis of OR75

EMS mutagenesis of OR75

M. Jones-Mortimer

B. Bachmann

B. Bachmann

B. Bachmann

B. Bachmann

B. Bachmann

R. Curtiss III

R. Curtiss III

J. R. Guest

M. Jones-Mortimer

* The system of genetic nomenclature is based on the recommendations of Demerec et al. (1966). Cymstrains respond to either cysteine or methionine.

$\dagger$ NG, $N$-methyl- $N^{\prime}$-nitro- $N$-nitrosoguanidine; EMS, ethyl methanesulphonate.

source (added as a $20 \%$, w/v, sterile solution after autoclaving the bulk medium); $5 \mathrm{ml}$ sulphur-free trace metals (Cole et al., 1974); and $12 \mathrm{~g}$ Oxoid agar. Inocula for batch cultures were aerated at $37^{\circ} \mathrm{C}$ for 6 to $8 \mathrm{~h}$ in $20 \mathrm{ml}$ Lennox (1955) broth and transferred to nitrogen-free salts supplemented with Lennox broth, $20 \mathrm{~mm}-\mathrm{NH}_{4} \mathrm{Cl}$ and $2 \mathrm{~mm}-\mathrm{NaNO}_{2}$, as described by Newman \& Cole (1978).

Preparation of cell-free extracts and enzyme assays. These were described previously (Newman \& Cole, 1978). Harvested bacteria resuspended in TEA buffer $(50 \mathrm{~mm}$-Tris/HCl, $5 \mathrm{mM}$-EDTA and $5 \mathrm{~mm}$-sodium ascorbate buffer, $\mathrm{pH} 8.0$ ) were broken in the French pressure cell. TEA buffer was used for all subsequent procedures.

Genetic methods. Bacteriophage P1kc released from an overnight culture of $E$. coli W1485E was used for transduction experiments (Lambden \& Guest, 1976). For conjugation experiments, early-exponential phase cultures of donor $(1 \mathrm{ml})$ and recipient $(10 \mathrm{ml})$ bacteria in Lennox broth were incubated at $37{ }^{\circ} \mathrm{C}$ without aeration. After $30 \mathrm{~min}$ (unless otherwise stated), $1 \mathrm{ml}$ of the mixed culture was transferred to $9 \mathrm{ml}$ minimal salts, vortexed vigorously for $1 \mathrm{~min}$ and plated on selective media. Strains auxotrophic for aromatic amino acids were grown on minimal agar supplemented with tryptophan, phenylalanine and tyrosine (each at $20 \mu \mathrm{g}$ $\left.\mathrm{ml}^{-1}\right)$ and sodium shikimate $(1 \mu \mathrm{M})$.

Mutants unable to reduce nitrite were isolated as described by Cole \& Ward (1973); the modified procedure was used to score the Nir phenotype of various strains (Newman \& Cole, 1978). Other procedures have been described by Newman \& Cole $(1977,1978)$.

\section{RESULTS}

Both nir $A$ and $\operatorname{nir} B$ mutants were isolated as strains unable to use nitrite as sole nitrogen source during anaerobic growth: other properties of the original isolates are summarized in Table 2 . The mutations were induced by treating wild-type bacteria with ethyl methane- 
Table 2. Comparison of two types of mutant of E. coli unable to reduce nitrite

\begin{tabular}{|c|c|c|c|c|c|c|}
\hline Strain & Phenotype & $\begin{array}{l}\text { Formate } \\
\text { hydrogen- } \\
\text { lyase }\end{array}$ & $\begin{array}{l}\text { Nitrite reduced } \\
\text { during growth } \\
(\mathrm{mm})\end{array}$ & $\begin{array}{c}\text { Final cell } \\
\text { density } \\
\left(A_{650}\right)\end{array}$ & $\begin{array}{l}\text { NADH- } \\
\text { nitrite oxido- } \\
\text { reductase* }\end{array}$ & $\begin{array}{c}\text { Cytochrome } \\
c_{552} \dagger\end{array}$ \\
\hline OR56 & Wild-type & + & $2 \cdot 0$ & $0.8 \overline{8}$ & 90 & 35 \\
\hline CB201 & $\mathrm{NirB}^{-}$ & - & 0.5 & 0.75 & 2 & 35 \\
\hline CB203 & $\mathrm{NirB}^{-}$ & + & $0 \cdot 4$ & 0.75 & 5 & 55 \\
\hline OR75 & Wild-type & + & $2 \cdot 0$ & 0.73 & 200 & 33 \\
\hline CB211 & $\mathrm{NirA}^{-}$ & - & $<0.1$ & 0.94 & 8 & $<5$ \\
\hline CB213 & $\mathrm{NirB}^{-}$ & + & $1 \cdot 1$ & 0.82 & $<2$ & 40 \\
\hline CB217 & $\mathrm{NirB}^{-}$ & + & ND & ND & $<2$ & 13 \\
\hline JM72 & $\mathrm{NirB}^{-}$ & + & $<0.1$ & ND & $<2$ & 112 \\
\hline
\end{tabular}

sulphonate (strains CB213 and CB217) or $N$-methyl- $N^{\prime}$-nit ro- $N$-nitrosoguanidine (CB201 CB203 and CB211). Some of the mutants might therefore carry secondary mutations unconnected with the nitrite reductase defect. Strain $\mathrm{CB} 201$ was resistant to $10 \mathrm{mM}-\mathrm{KClO}_{3}$ during anaerobic growth and was therefore unable to catalyse the formate hydrogenlyase reaction. Strains CB201, CB213 and CB217 required either cysteine or methionine during growth in minimal media and CB211 was auxotrophic for unidentified growth factors.

Rates of synthesis of cytochrome $c_{552}$, glutamate dehydrogenase and glutamine synthetase and, unlike the nirA strains described previously, the regulation of the latter two enzymes by $\mathrm{NH}_{4}{ }^{+}$were similar in nirB mutants and wild-type bacteria. The $\mathrm{NirB}^{-}$strains reduced nitrite extremely slowly during growth and washed bacterial suspensions were defective in nitrite reduction with glucose as the electron donor (Table 2). There was a close correlation between the NADH-dependent nitrite reductase activity of cell-free extracts and the rates of nitrite reduction during growth (Table 2).

\section{Conjugation experiments to map the nir B gene}

Data from conjugation experiments designed to determine the approximate chromosomal location of the defective gene responsible for the $\mathrm{NirB}^{-}$phenotype are summarized in Table 3 , together with conclusions derived from them. The first four experiments indicate that strain CB201 carries a wild-type nirA ${ }^{+}$gene and that the defective nitrite reductase gene, designated nirB201, is probably located between the his and $i l v$ operons, possibly close to $\arg A$. The preferential inheritance of the recipient $\operatorname{nir} B$ allele by the recombinants when streptomycin was used to select against the donor suggested that the $\operatorname{nir} B$ gene is located close to the streptomycin-resistance determinant, $r p s L$. This was confirmed in experiments with the streptomycin-resistant $\mathrm{Hfr}$ strain $\mathrm{AB} 312$ in which nir $B^{+}$was shown to be closely linked to the donor rpsL and $\mathrm{mal}^{+}$genes (Table 3, experiments 5 and 6).

The plasmids KLF33 and KLF41 which carry wild-type genes covering, respectively, the 82 to 89 and 68 to 74 minute regions of the chromosome were transferred into recipient nirB strains (Table 3, experiments 7 and 8). All $\mathrm{Mal}^{+}$transconjugants which had inherited KLF41 were $\mathrm{Nir}^{+}$; KLF41 therefore carries a wild-type $\operatorname{nir} B^{+}$allele which is trans-dominant to the defective nir $B$ allele. In contrast, KLF33 did not complement the nir $B$ defect carried by strain CB63.

Genes adjacent to the mal operon have been deleted from strains Lin 13 and Lin72 Although Lin72 is $\mathrm{Nir}^{+}$, Lin13 is $\mathrm{Nir}^{-}$and is also auxotrophic for unknown growth requirements other than biotin, aromatic amino acids and cysteine. We suggest that the nirB gene, or another gene close to it, is absent or defective in Lin 13. 
Table 3. Conjugation data to determine the approximate location of the nirB gene

\begin{tabular}{|c|c|c|c|c|c|}
\hline $\begin{array}{l}\text { Expt } \\
\text { no. }\end{array}$ & Donor & Recipient & $\begin{array}{c}\text { Selected } \\
\text { phenotype }\end{array}$ & $\begin{array}{r}\text { Percentag } \\
\text { of } \mathrm{Nir}^{+} \\
\text {recom- } \\
\text { binants }\end{array}$ & Conclusion \\
\hline 1 & CB201 NirB- Chl ${ }^{R}$ & CB98 nirA $\mathrm{Chl}^{\mathrm{s}} \operatorname{trp}$ his rpsL & His $^{+} \operatorname{Str}^{\mathbf{R}}$ & 32 & $\begin{array}{l}\text { Chl defect in CB201 } \\
\text { is unlinked to nir } A \text { or } \\
\text { nir } B \\
\text { nir } B \text { is not close to } \\
\text { nir } A \text { or his and } \\
\text { CB201 is nir } A^{+}\end{array}$ \\
\hline 2 & CB201 NirB- & $22 \mathrm{~A} 43 \mathrm{Nir}^{+}$mal arg A ilv rpsL & $\begin{array}{l}\mathrm{Mal}^{+} \mathrm{Str}^{\mathrm{R}} \\
\mathrm{Arg}^{+} \mathrm{Str}^{\mathrm{R}} \\
\mathrm{Ilv}^{+} \mathrm{Str}^{\mathrm{B}}\end{array}$ & $\begin{array}{l}75 \\
68 \\
82\end{array}$ & $\begin{array}{l}\text { nir } B \text { is not closely } \\
\text { linked to mal, } \arg A \text { or } \\
\text { ilv but could be close } \\
\text { to rpsL }\end{array}$ \\
\hline \multirow[t]{3}{*}{3} & OR75 $\mathrm{Nir}^{+}$ & CB63 nirB pro thr metB rpsL & $\begin{array}{l}\text { Early } \text { Pro }^{+} \text {Str }^{\mathbf{B}} \\
\text { Late } \text { Pro }^{+} \text {Str }^{\mathbf{R}}\end{array}$ & $\begin{array}{l}0 \\
0\end{array}$ & $\begin{array}{l}\text { nir } B \text { is located anti- } \\
\text { clockwise with respect } \\
\text { to pro }\end{array}$ \\
\hline & & & $\begin{array}{l}\text { Early } \mathrm{Thr}^{+} \mathrm{Str}^{\mathrm{R}} \\
\text { Late } \mathrm{Thr}^{+} \mathrm{Str}^{\mathrm{R}}\end{array}$ & $\begin{array}{l}\mathbf{0} \\
\mathbf{0}\end{array}$ & $\begin{array}{l}\text { nirB is located anti- } \\
\text { clockwise with respect } \\
\text { to } t h r\end{array}$ \\
\hline & & & $\begin{array}{l}\text { Early } \mathrm{Met}^{+} \mathbf{S t r}^{\mathbf{R}} \\
\text { Late } \mathbf{M e t}^{+} \mathbf{S t r}^{\mathbf{R}}\end{array}$ & $\begin{array}{r}8 \\
75\end{array}$ & $\begin{array}{l}\text { nir } B \text { is located anti- } \\
\text { clockwise with respect } \\
\text { to met } B\end{array}$ \\
\hline 4 & KL209 $\mathrm{Nir}^{+}$ & CB69 nirB ilv argA $r s p L$ & $\begin{array}{l}\mathbf{I l v}^{+} \mathbf{S t r}^{\mathbf{R}} \\
\mathbf{A r g}^{+} \mathbf{S t r}^{\mathbf{R}}\end{array}$ & $\begin{array}{r}7 \\
61\end{array}$ & $\begin{array}{l}\operatorname{nir} B \text { is closer to } \arg A \\
\text { than to ilv }\end{array}$ \\
\hline 5 & AB312 $\mathrm{Nir}^{+} r p s L$ & CB201 nirB rpsL $L^{+}$ & $\operatorname{Str}^{R}$ & 90 & $\operatorname{nir} B$ is close to $r p s L$ \\
\hline 6 & AB312 $\mathrm{Nir}^{+}$leu & CB68 nirB mal leu ${ }^{+}$ & $\mathrm{Mal}^{+} \mathrm{Leu}^{+}$ & 83 & $\operatorname{nir} B$ is close to $\mathrm{mal}$ \\
\hline 7 & KLF33/JC1553 & CB63 nirB metB & $\mathrm{Met}^{+}$ & 0 & $\begin{array}{l}\text { nir } B \text { is not located } \\
\text { between minutes } 82 \\
\text { and } 89, \text { or is dominant } \\
\text { to nir } B^{+}\end{array}$ \\
\hline 8 & KLF41/JC1553 & CB68 nirB mal & $\mathrm{Mal}^{+}$ & 100 & $\begin{array}{l}\text { nir } B \text { is located between } \\
\text { minutes } 68 \text { and } 74, \text { on } \\
\text { the segment carried by } \\
\text { KLF } 41 \text {; nir } B^{+} \text {is } \\
\text { trans-dominant to } \\
\text { nir } B\end{array}$ \\
\hline
\end{tabular}

Transduction experiments to locate the nirB gene

The conjugation data suggested that nir $B$ might be cotransducible by bacteriophage $P 1$ with $\mathrm{mal}^{+}$or $\mathrm{aroB}^{+}$. This was confirmed when AB2847 was transduced to $\mathrm{Mal}^{+}$and $\mathrm{Aro}^{+}$ with phage which had been propagated in CB201: 25\% of the $\mathrm{Aro}^{+}$and 7\% of the $\mathrm{Mal}^{+}$ transductants were $\mathrm{Nir}^{-}$(Table 4, experiment 1). The $\mathrm{Nir}^{-}$phenotypes of strains $\mathrm{CB} 203$, CB213, CB217 and of two other less studied isolates were also cotransducible with aro $B^{+}$ and $\mathrm{mal}^{+}$at similar frequencies (Table 4, experiment 2, and data not shown). These nirB defects are therefore located on the $\operatorname{rps} L$ side of $\operatorname{aroB}$, probably close to cys $G$ (Fig. 1).

The only cysG mutant available was JM72: this reduced nitrite even more slowly than the new NirB- mutants. Normal quantities of cytochrome $c_{552}$ were synthesized by JM72, but NADH-dependent nitrite reductase was inactive. Strain JM72 was therefore phenotypically $\mathrm{NirB}^{-}$.

Strain CB201 was transduced to rps $L$ with phage P1 that had been propagated in JM72 and the Nir and Cys phenotypes of streptomycin-resistant transductants were determined (Table 4, experiment 3). Methionine was added to selective media to satisfy the cysteine or methionine $\left(\mathrm{Cym}^{-}\right)$requirement of the recipient. All $r p s L$ transductants were $\mathrm{Nir}^{-}$. Although $93 \%$ had retained the $\mathrm{Cys}^{+} \mathrm{Cym}^{-}$phenotype of the recipient, it was apparent that the defec- 
Table 4. Transductions to establish the relative positions of the nirB, cys $G$ and aro $B$ genes

\begin{tabular}{|c|c|c|c|c|c|c|}
\hline $\begin{array}{l}\text { Expt } \\
\text { no. }\end{array}$ & Donor & Recipient & $\begin{array}{l}\text { Selected } \\
\text { phenotype }\end{array}$ & $\begin{array}{l}\text { No. } \\
\text { scored }\end{array}$ & $\begin{array}{l}\text { Unselected } \\
\text { recombinant } \\
\text { classes }\end{array}$ & $\begin{array}{c}\text { Per- } \\
\text { centage } \\
\text { in each } \\
\text { class }\end{array}$ \\
\hline \multirow[t]{2}{*}{1} & CB201 nirB201 & AB2847 aroB mal & $\mathrm{Aro}^{+}$ & 108 & $\begin{array}{l}\mathrm{Mal}^{+} \mathrm{Nir}^{+} \\
\mathrm{Mal}^{+} \mathrm{Nir}^{-} \\
\mathrm{Mal}^{-} \mathrm{Nir}^{+} \\
\mathrm{Mal}^{-} \mathrm{Nir}^{-}\end{array}$ & $\begin{array}{r}21 \\
8 \\
50 \\
21\end{array}$ \\
\hline & & & $\mathrm{Mal}^{+}$ & 108 & $\begin{array}{l}\text { Aro }^{+} \mathrm{Nir}^{+} \\
\text {Aro }^{+} \mathrm{Nir}^{-} \\
\text {Aro- }^{-} \mathrm{Nir}^{+} \\
\text {Aro- } \mathrm{Nir}^{-}\end{array}$ & $\begin{array}{r}23 \\
6 \\
71 \\
0\end{array}$ \\
\hline 2 & CB88 nirB203 & $\mathrm{AB} 2847$ aro $B$ & $\mathrm{Aro}^{+}$ & 107 & $\begin{array}{l}\mathrm{Nir}^{+} \\
\mathrm{Nir}^{-}\end{array}$ & $\begin{array}{l}70 \\
30\end{array}$ \\
\hline 3 & $\mathrm{JM} 72$ rpsL cysG & CB201 nirB201 Cym- & $\operatorname{Str}^{\mathbf{R}}$ & 100 & $\begin{array}{l}\mathrm{Cys}^{+} \mathrm{Nir}^{+} \\
\mathrm{Cys}^{+} \mathrm{Nir}^{-*} \\
\mathrm{Cys}^{-} \mathrm{Nir}^{+} \\
\text {Cys }^{-} \mathrm{Nir}^{-}\end{array}$ & $\begin{array}{c}0 \\
93 * \\
0 \\
7\end{array}$ \\
\hline \multirow[t]{2}{*}{4} & OR75 nir $^{+}$cys $^{+}$mal $^{+}$ & $\mathrm{JM} 72$ cysG $\mathrm{Mal}^{-}$ & Cys $^{+}$ & 100 & $\begin{array}{l}\mathrm{Nir}^{+} \\
\mathrm{Nir}^{-}\end{array}$ & $\begin{array}{r}100 \\
0\end{array}$ \\
\hline & & & $\mathrm{Mal}^{+}$ & 100 & $\begin{array}{l}\mathrm{Cys}^{+} \mathrm{Nir}^{+} \\
\text {Cys }^{+} \mathrm{Nir}^{-} \\
\mathrm{Cys}^{-} \mathrm{Nir}^{+} \\
\text {Cys }^{-} \mathrm{Nir}^{-}\end{array}$ & $\begin{array}{r}100 \\
0 \\
0 \\
0\end{array}$ \\
\hline 5 & AB2847 aroB mal & JM72 cysG $\mathrm{Nir}^{-} \mathrm{Mal}^{-}$ & Cys $^{+}$ & 105 & $\begin{array}{l}\mathrm{Mal}^{+} \mathrm{Aro}^{+} \mathrm{Nir}^{+} \\
\mathrm{Mal}^{+} \mathrm{Aro}^{+} \mathrm{Nir}^{-} \\
\mathrm{Mal}^{+} \mathrm{Aro}^{-} \mathrm{Nir}^{+} \\
\mathrm{Mal}^{+} \mathrm{Aro}^{-} \mathrm{Nir}^{-} \\
\mathrm{Mal}^{-} \mathrm{Aro}^{+} \mathrm{Nir}^{+} \\
\mathrm{Mal}^{-} \mathrm{Aro}^{+} \mathrm{Nir}^{-} \\
\mathrm{Mal}^{-} \mathrm{Aro}^{-} \mathrm{Nir}^{+} \\
\mathrm{Mal}^{-} \mathrm{Aro}^{-} \mathrm{Nir}^{-}\end{array}$ & $\begin{array}{r}53 \\
0 \\
11 \\
0 \\
0 \\
0 \\
37 \\
0\end{array}$ \\
\hline \multirow[t]{2}{*}{6} & JM72 cysG $\mathrm{Mal}^{-}$ & AB2847 aroB mal & $\mathrm{Aro}^{+}$ & 97 & $\begin{array}{l}\mathrm{Mal}^{+} \mathrm{Cys}^{+} \mathrm{Nir}^{+} \\
\mathrm{Mal}^{+} \mathrm{Cys}^{-} \mathrm{Nir}^{-} \\
\mathrm{Mal}^{-} \mathrm{Cys}^{+} \mathrm{Nir}^{+} \\
\mathrm{Mal}^{-} \mathrm{Cys}^{-} \mathrm{Nir}^{-}\end{array}$ & $\begin{array}{r}33 \\
8 \\
46 \\
13\end{array}$ \\
\hline & & & $\mathrm{Mal}^{+}$ & 97 & $\begin{array}{l}\text { Aro }^{+} \mathrm{Cys}^{+} \mathrm{Nir}^{+} \\
\text {Aro }^{+} \mathrm{Cys}^{-} \mathrm{Nir}^{-} \\
\text {Aro }^{-} \mathrm{Cys}^{+} \mathrm{Nir}^{+} \\
\text {Aro }^{-} \mathrm{Cys}^{-} \mathrm{Nir}^{-}\end{array}$ & $\begin{array}{r}38 \\
0 \\
62 \\
0\end{array}$ \\
\hline 7 & CB88 nirB203 & CB89 nirB202 cysG & $\mathrm{Cys}^{+}$ & 269 & $\begin{array}{l}\mathrm{Nir}^{+} \\
\mathrm{Nir}^{-}\end{array}$ & $\begin{array}{r}5 \\
95\end{array}$ \\
\hline
\end{tabular}

* All of these transductants were Cym-

tive cys $G$ allele in the donor has been cotransduced with $r p s L$ at a low frequency. The absence of any $\mathrm{Nir}^{+}$transductants showed that the nitrite reductase defect carried by strain JM72 is either not cotransducible with the streptomycin resistance determinant, $r p s L$, or is located extremely close to the nitrite reductase defect, nirB201, in strain CB201. The defect in strain JM72 was tentatively designated nirB202.

Totally unexpected results were obtained when JM72 was transduced with P1 that had been propagated in the wild-type, OR75. All Cys ${ }^{+}$transductants were $\mathrm{Nir}^{+}$and all $\mathrm{Mal}^{+}$transductants were $\mathrm{Cys}^{+} \mathrm{Nir}^{+}$(Table 4, experiment 4).

The relative positions of the nirB202, cysG and $\operatorname{aroB}^{+}$genes in strain JM72 were determined in reciprocal transductional crosses with the Aro- $\mathrm{Mal}^{-}$strain AB2847. Both the 
donor and the recipient were $\mathrm{Mal}^{-}$: nevertheless, almost identical numbers of $\mathrm{Mal}^{+}$and either $\mathrm{Aro}^{+}$or $\mathrm{Cys}^{+}$transductants were isolated on appropriate selective media (Table 4, experiments 5 and 6 ). This high recombination frequency suggests that one of these strains carries a defective crp gene at minute 72.5 rather than a defect in the mal operon at minute 74 on the $E$. coli linkage map. The distribution of inheritance of unselected markers was consistent with a defective mal gene in strain AB2847 and a defective $c r p$ gene in JM72. If this is correct, strain JM72 should be unable to ferment arabinose (Pastan \& Perlman, 1970): this prediction was confirmed. Furthermore, all $\mathrm{Cys}^{+}$transductants were also $\mathrm{Nir}^{+}$, and $\mathrm{Cys}^{-}$recombinants were $\mathrm{Nir}^{-}$. The $\mathrm{Cys}^{-}$and $\mathrm{Nir}^{-}$defects of strain JM72 therefore appear to be due either to two defects extremely close together or to a single defect which might be a point mutation or a deletion.

The close proximity of the nirB202 and nirB203 mutations was established when strain CB89 nirB202 cys $G$ was transduced to $\mathrm{Cys}^{+}$with phage propagated in CB88 nirB203 Cys $^{+}$. Only $5 \%$ of the 269 transductants screened were Nir $^{+}$(Table 4, experiment 7).

\section{Simultaneous reversion of $\mathrm{NirB}$ mutants to $\mathrm{Cys}^{+}$and $\mathrm{Nir}^{+}$}

Samples $\left(0 \cdot 1 \mathrm{ml} ; 5 \times 10^{8}\right.$ bacteria) of an overnight culture of strain CB201 were spread on glucose-minimal agar plates; some plates were seeded with a small crystal of $N$-methyl$N^{\prime}$-nitro- $N$-nitrosoguanidine. $\mathrm{Cys}^{+}$revertants were readily isolated on both types of plate: all were $\mathrm{Nir}^{+}$. Similar results were obtained with $\mathrm{Cys}^{+}$revertants of CB213 and CB217, but no $\mathrm{Cys}^{+}$revertants of JM72 were isolated in approximately 10 independent experiments, or on the control plates from 20 transduction experiments.

\section{Biochemical properties of isogenic nirB and nir $B^{+}$transductants}

The nitrite reductase activity and concentration of cytochrome $c_{552}$ in cell-free extracts of various pairs of otherwise isogenic nirB and nir $B^{+}$strains were determined. In each case, the nir $B$ mutant was deficient in NADH-dependent nitrite reductase activity. Furthermore, with the exception of nirB203 strains, each mutant either required cysteine for growth, or its growth rate was faster in the presence of cysteine or methionine.

\section{DISCUSSION}

Chromosomal location of the nir $B^{+}$gene and its identity with $c y s G^{+}$. The determination of the relative positions of the $\operatorname{rps} L$, nirB, cysG, aroB and mal genes was hampered by the incorrect assumption that strain JM72 carried a defect in the mal operon rather than in the crp gene and by difficulties in scoring the Cys and Nir phenotypes of different classes of recombinant. Cys ${ }^{-}$transductants were frequently lost during transduction procedures, so the observed recombination frequencies between the $c y s G$ and $a r o B^{+}$alleles of JM72 were abnormally high. The growth rate and therefore the rate of nitrite reduction during anaerobic growth in media supplemented with nitrite were higher for $\mathrm{Aro}^{+}$than for $\mathrm{Aro}^{-}$strains, so it was essential to score unselected auxotrophic markers and sort recombinants into their various classes before their Nir phenotypes could be determined. Finally, there were wide variations in the response of different $\mathrm{NirB}^{-}$isolates to cysteine or methionine. Thus, JM72 was an obligate cysteine auxotroph; CB201, CB213 and CB217 required either cysteine or methionine, but the growth rate of strain CB203 was inhibited by cysteine and this mutant formed normal-sized colonies on unsupplemented minimal agar. Despite these complications, the results in Table 4 establish that the $\mathrm{NirB}^{-}$phenotypes are pleiotropic effects of mutations in the cys $G$ gene which is located between $c r p$ and $a r o B$, as shown in Fig. 1.

The lack of a direct selection procedure for $\mathrm{Nir}^{+}$strains (other than the restoration of a $\mathrm{Cys}^{+}$phenotype) and the high reversion frequencies of the new $\mathrm{NirB}^{-}$isolates have pre- 
(a)
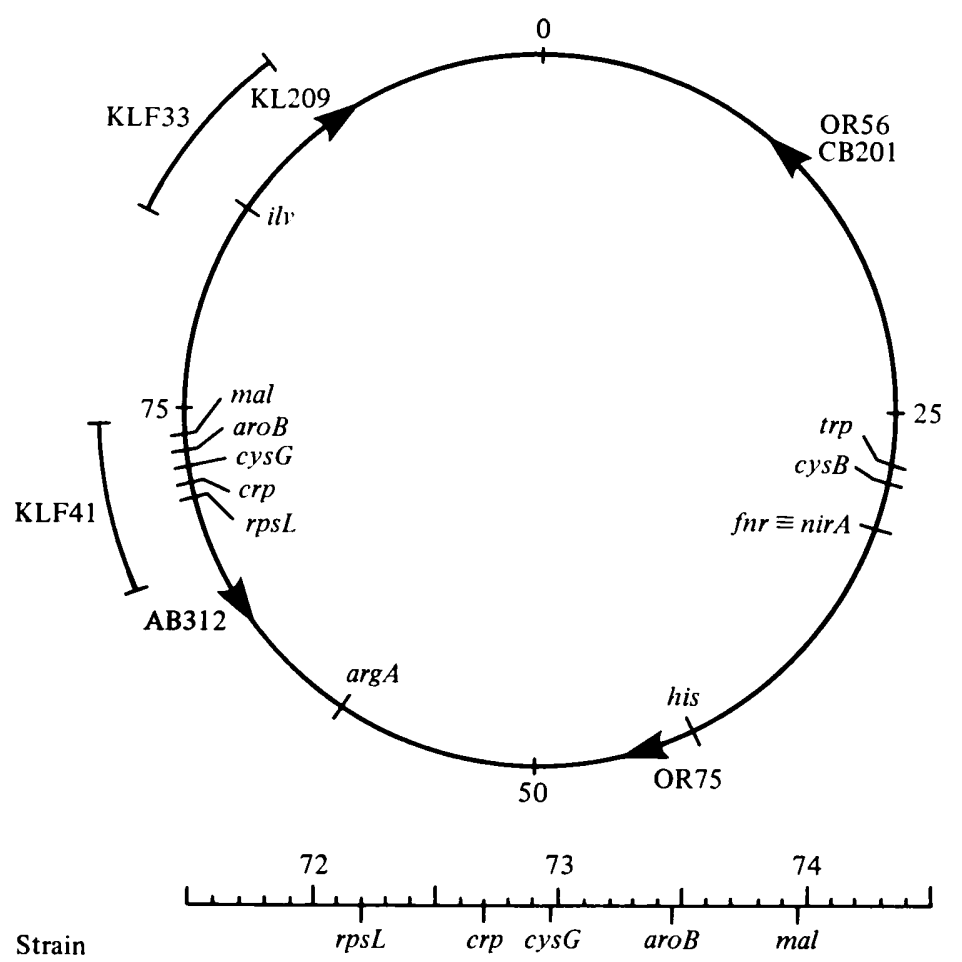

b)

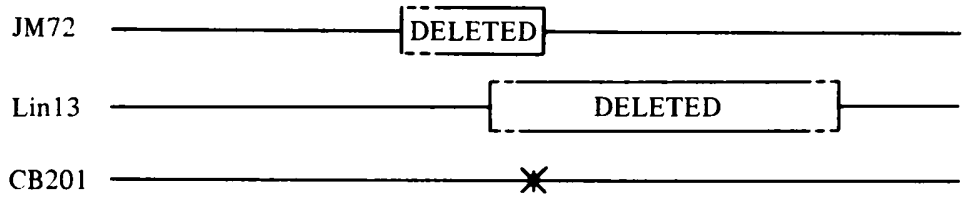

CB203

Fig. 1. Location of the genetic defects in various $\mathrm{NirB}^{-}$mutants. In $(a)$ the relative positions of genes used to locate the nir $B$ defects in the minute 72 to 74 region of the $E$. coli chromosome are shown: arrows indicate the origin of transfer of the various $\mathrm{Hfr}$ strains used for conjugation experiments. This region is expanded in $(b)$ to show the relative positions of four of these lesions.

vented us from determining whether they belong to one or more complementation groups. Nevertheless, the isolation of $13 \mathrm{Nir}^{+}$recombinants from a transduction experiment in which CB88 nirB203 was the donor and CB89 nirB202 cysG the recipient indicates that the nirB203 defect is to the right of the nirB202 defect (Fig. $1 b$ ). The stability of JM72 to reversion to $\mathrm{Cys}^{+}$or $\mathrm{Nir}^{+}$and our failure to isolate $\mathrm{Cys}^{+} \mathrm{Crp}^{-}$transductants suggest that JM72 is deleted for at least part of the $\operatorname{cys} G$ (nirB) region and that the postulated deletion terminates outside the $c r p$ gene (Fig. $1 b$ ). Furthermore, the defect carried by CB201 lies within, or extremely close to, the end of this deletion.

The biochemical basis for the pleiotropic phenotype of cys $G$ strains. The pleiotropicnegative phenotypes of $\operatorname{cys} G$ (nirB) mutants are inconsistent with the proposal that nir $B$ is the structural gene for NADH-nitrite oxidoreductase. It is more likely that this gene encodes a protein which must be functional for the six-electron reduction of both $\mathrm{SO}_{3}{ }^{2-}$ to $\mathrm{S}^{2-}$ and $\mathrm{NO}_{2}{ }^{-}$to $\mathrm{NH}_{4}{ }^{+}$. Structural similarities between sulphite reductase from $E$. coli and nitrite reductase from the fungus Neurospora crassa include the presence of sirohaem as well as FAD and a non-haem iron-sulphur centre (Siegel et al., 1973; Greenbaum et al., 
1978). Although sirohaem could not be found in small samples of nitrite reductase from E. coli purified previously in this laboratory (Coleman et al., 1978; Jackson et al., 1979), a haem signal similar to that of sirohaem has recently been detected spectroscopically ( $R$. Jackson, unpublished results). When the protein is purified to apparent homogeneity (as judged by sodium dodecyl sulphate-polyacrylamide gel electrophoresis) in stabilizing buffer, it is both highly active and orange. In the absence of stabilizing agents (FAD, EDTA and ascorbate) it rapidly becomes inactive, colourless and haem-free. We suggest, therefore, that the NADH-nitrite and NADPH-sulphite oxidoreductases from $E$. coli share a common prosthetic group, sirohaem, and that cys $G$ encodes an enzyme required for sirohaem synthesis. The hem $A$ product, $\delta$-aminolaevulinic acid synthase, is also required for sirohaem synthesis (McConville \& Charles, 1979), so the above hypothesis is consistent with the previously unexplained observation that hem $A$ mutants of $E$. coli are unable to reduce nitrite (Cole \& Brown, 1980). The $\mathrm{Cys}^{+} \mathrm{Nir}^{-}$phenotype of CB203 would be compatible with this hypothesis if there are multiple genes for sirohaem synthesis in the $c y s G$ region, only some of which are required for inserting sirohaem into sulphite reductase. This implies that although the haem groups of sulphite and nitrite reductases are similar, they may not be identical. Alternatively, CB203 might be a leaky mutant which synthesizes sufficient sirohaem to satisfy the very low rate of cysteine biosynthesis but insufficient for nitrite reduction. A third possibility is that CB203 is defective in another nitrite reductase gene which is not involved in sirohaem synthesis (see also Abou-Jaoude et al., 1979). Until the tentative identification of sirohaem as a prosthetic group of nitrite reductase and the role of the cys $G$ (nir $B$ ) product in its synthesis have been confirmed, we suggest that the use of the nir $B$ designation should be discontinued.

We are grateful to Dr M. Jones-Mortimer for providing strain JM72 and for drawing our attention to the possibility that $c y s G^{+}$might be the structural gene for an enzyme involved in sirohaem synthesis. B. M. N. was supported by a Research Studentship from the Science Research Council.

\section{REFERENCES}

Abou-Jaoude, A., Pascal, M. C. \& Chippaux, M. (1979). Nitrite reduction in Escherichia coli: genetic analysis of nir mutants. Molecular and General Genetics 167, 113-118.

BachmanN, B. J., Low, K. B. \& Taylor, A. L. (1976). Recalibrated linkage map of Escherichia coli K12. Bacteriological Reviews 40, 116-167.

Chippaux, M., Giudici, D., Abou-Jaoude, A., Casse, F. \& Pascal, M. C. (1978). Mutation leading to the total lack of nitrite reductase activity in Escherichia coli K12. Molecular and General Genetics 160, 225-229.

Cole, J. A. \& Brown, C. M. (1980). Nitrite reduction to ammonia by fermentative bacteria: a short circuit in the biological nitrogen cycle. FEMS Microbiology Letters 7, 65-72.

COLE, J. A. \& WARD, F. B. (1973). Nitrite reductasedeficient mutants of Escherichia coli K12. Journal of General Microbiology 76, 21-29.

Cole, J. A., Coleman, K. J., Compton, B. E., Kavanagh, B.M. \& Keevil, C. W. (1974). Nitrite and ammonia assimilation by anaerobic continuous cultures of Escherichia coli. Journal of General Microbiology 85, 11-22.

Coleman, K. J., Newman, B. M., Cornish-BowDEN, A. J. \& COLE, J. A. (1978). Nitrite reduction by bacteria. In Microbiology-1978, pp. 334-338.
Edited by D. Schlessinger. Washington, D.C.: American Society for Microbiology.

Demerec, M., Adelberg, E. A., Clark, A. J. \& HARTMAN, P. E. (1966). A proposal for a uniform nomenclature in bacterial genetics. Genetics 54, 61-76.

Greenbaum, P., Prodouz, K. N. \& Garrett, R. H. (1978). Preparation and some properties of homogeneous Neurospora crassa NADPHnitrite reductase. Biochimica et biophysica acta 526, 52-64.

JaCkson, R., Cornish-Bowden, A. \& Cole, J. A. (1979). Prosthetic groups of NADH-dependent nitrite reductase from Escherichia coli K12. Society for General Microbiology Quarterly 6, 165.

LAmBden, P. R. \& Guest, J. R. (1976). Mutants of Escherichia coli $\mathrm{K} 12$ unable to use fumarate as an anaerobic electron acceptor. Journal of General Microbiology 97, 145-160.

LENNOX, E. S. (1955) Transduction of linked genetic characters of the host by bacteriophage P1. Virology 1, 190-206.

McConville, M. L. \& Charles, H. P. (1979). Isolation of haemin-requiring mutants of Escherichia coli K12. Journal of General Microbiclogy 113, 155-164. 
Newman, B. M. \& Cole, J. A. (1977). Lack of a regulatory function for glutamine synthetase protein in the synthesis of glutamate dehydrogenase and nitrite reductase in Escherichia coli K12. Journal of General Microbiology 98, 369-377.

Newman, B. M. \& Cole, J. A. (1978). The chromosomal location and pleiotropic effects of mutations of the nir $A^{+}$gene of Escherichia coli K12: the essential role of nir $A^{+}$in nitrite reduction and in other anaerobic redox reactions. Journal of General Microbiology 106, 1-12.
Pastan, I. \& Perlman, R. (1970). Cyclic adenosine monophosphate in bacteria. Science 169, 339-344.

Siegel, L. M., MurPhy, M. J. \& Kamin, H. (1973). Reduced nicotinamide adenine dinucleotide phosphate-sulfite reductase of enterobacteria. 1. The Escherichia coli hemoflavoprotein: molecular parameters and prosthetic groups. Journal of Biological C'hemistry 248, 251-264. 